\title{
Pengaruh Penerapan Model Pembelajaran Kooperatif Teknik Berkirim Salam dan Soal Terhadap Kemampuan Pemahaman Matematis Siswa SMP
}

\author{
Nur Baeti ${ }^{1)}$, Mikrayanti ${ }^{2)}$ \\ Dosen Program Studi Pendidikan Matematika, STKIP Bima \\ Email: nurbaeti_betty7@yahoo.com
}

\begin{abstract}
Abstrak: Penelitian ini bertujuan untuk mengetahui pengaruh penerapan model pembelajaran kooperatif teknik berkirim salam dan soal terhadap kemampuan pemahaman matematis siswa SMP. Penelitian ini termasuk dalam penelitian eksperimen semu. Desain penelitian ini menggunakan control group pretest and posttest design. Penelitian ini menggunakan satu kelas eksperimen dan satu kelas kontrol. Pada kelas eksperimen diberi perlakuan pembelajaran dengan model pembelajaran kooperatif teknik berkirim salam, sedangkan kelas kontrol diberi perlakuan pembelajaran dengan pembelajaran konvensional dengan metode diskusi, ceramah dan tanya jawab. Populasi penelitian adalah seluruh siswa kelas VIII SMP Negeri 12 Kota Bima. Teknik pengambilan sampel yang digunakan adalah cluster random sampling, sehingga diperoleh kelas VIII B sebagai kelas eksperimen dan VIII A sebagai kelas kontrol. Teknik pengumpulan data menggunakan tes uraian. Uji hipotesis menggunakan uji independent sample t-test. Hasil penelitian ini menunjukkan bahwa model kooperatif teknik berkirim salam berpengaruh terhadap kemampuan pemahaman matematis siswa di SMP Negeri 12 Kota Bima.
\end{abstract}

\section{Kata Kunci: Model Kooperatif Teknik Berkirim Salam, Kemampuan Pemahaman Matematis}

\section{PENDAHULUAN}

Pembelajaran merupakan upaya untuk membelajarkan siswa agar memiliki kompetensi berupa pengetahuan, keterampilan, dan sikap (Pribadi,2011).Pembelajaran dimaksudkan agar siswa mampu mewujudkan prilaku belajar yang efektif. Suyono dan Hariyanto (2012), mengatakan bahwa siswa harus berani bertanya dan mengeluarkan pendapatnya. Berupaya dalam menyelesaikan tugas dengan benardan melakukan evaluasi terhadap hasil pekerjaan serta segera memperbaiki kesalahan jika ditemukan. Selain itu siswa belajar berpartisipasi secara aktif dalam menyelesaikan tugas, menjalin hubungan sosial dan dapat menilai sendiri proses dan hasil belajar (Warsono dan Hariyanto, 2012).

Peran guru dalam proses pembelajaran adalah dengan menyediakan kondisi belajar yang kondusif, menyediakan sarana dan prasarana yang memungkinkan terjadinya dialog terutama antara sesama siswa dan antara siswa dengan guru. Upaya guru dalam proses ini adalah dengan memotivasi siswa untuk dapat menguraikan ide-idenya dan memaparkan konsep yang diyakininya, guru harus bisa bertanya untuk merangsang pemikiran siswa danmampu menguasai pokok bahasan yang menjadi fokus pembelajaran sehingga dapat menerima gagasan murid yang berbeda dan menghargai apapun pendapat siswa.

Guru harus mampu mengaktifkan siswa, membangun semangat tim belajar dan kolaborasi antar siswa yaitu dengan menerapkan berbagai variasi metode mengajar yang sesuai dengan tujuan pembelajaran (Suyono dan Hariyanto, 2012). Tujuan pembelajaran dapat tercapai jika metode yang dipilih tepat. Hal ini diperkuat oleh pendapat Djamarah dan Aswan (2010) yang mengatakan bahwa metode mempunyai andil yang cukup besar dalam kegiatan belajar mengajar.kemampuan yang diharapkan dapat diiliki oleh anak didik, akan ditentukan oleh kerelevansian penggunaan suatu metode yang sesuai dengan tujuan. Tujuan pembelajaran akan dapat dicapai dengan penggunaan metode yang tepat sesuai dengan standar keberhasilan yang terpatri didalam suatu tujuan. 
Hasil observasi yang dilakukan oleh peneliti di SMP Negeri 12 Kota Bima bahwa terbukti bahwa matematika itu sulit ditunjukkan dengan hasil nilai ulangan harian siswa kelas VIII, tingkat keberhasilannya hanya mencapai 27\%. Dengan melihat hasil ulangan siswa sehingga perlu dilakukan perubahan-perubahan dalam pengorganisasian kelas, penggunaaan metode mengajar, strategi belajar-mengajar, maupun sikap dan karakteristik guru dalam mengelola proses belajar mengajar, bertindak selaku administrator yang berusaha menciptakan kondisi belajar yang efektif sehingga memungkinkan proses belajarmengajar, mengembangkan bahan pelajaran dengan baik, dan meningkatkan kemampuan siswa untuk menyimak pelajaran yang menguasai tujuan-tujuan pendidikan yang harus mereka capai. Sehingga guru dituntut mampu mengelola proses belajar mengajar yang memberikan rangsangan kepada peserta didik sehingga ia mau belajar karena peserta didiklah subjek utama dalam belajar. Dalam menciptakan kondisi belajar-mengajar yang efektif harus ada partisipasi aktif dari peserta didik, apalagi dalam pembelajaran matematika. Guru sebagai orang yang memegang peranan penting dalam pembelajaran, diharapkan mampu menciptakan kondisi belajar yang dapat melibatkan siswa secara aktif melalui model pembelajaran kooperatif teknik berkirim salam.

$$
\text { Pembelajaran kooperatif lebih }
$$

menekankan interaksi antar peserta didik, sehingga peserta didik akan melakukan komunikasi aktif dengan sesama temannya dan di kelas kooperatif peserta didik belajar bersama dalam kelompok-kelompok kecil yang terdiri dari 4-6 orang peserta didik yang sederajat tetapi heterogen, kemampuan, jenis kelamin, suku/ras, dan satu sama lain saling membantu (Wahyuni, 2004; Trianto, 2007). Adapun langkah-langkah dalam pembelajaran kooperatif memerlukan partisipasi aktif dari peserta didik. dalam suatu pembelajaran yaitu: 1) menyampailan tujuan dan memotivasi peserta didik; 2) menyajikan informasi; 3) mengorganisasikan siswa ke dalam kelompok kooperatif; 4) membimbing kelompok bekerja dan belajar; 5) evaluasi; 6) memberikan penghargaan

Kooperatif memiliki banyak teknik pembelajaran, namun dakam penelitian ini dipilihlah teknik berkirim salam dan soal. Menurut Lie (2010), langkah-langkah model pembelajaran kooperatif teknik berkirim salam dan soal yaitu: a) persiapan; b) pembentukan kelompok; c) memberikan ringkasan materi; d) diskusi pembuatan soal; e) bertamu ke kelompok lain dengan membawa soal; f) kembali ke kelompok semula; g) mengerjakan soal kiriman; h) mencocokkan jawaban dari kelompok penerima dengan pengirim soal.

Setelah memahami model pembelajaran kooperatif teknik berkirim salam dan soal diharapkan akan menciptakan situasi belajar yang menyenangkan bagi siswa. Karena di dalam proses belajar mengajar tidak monoton pasif duduk dibangku saja, siswa bisa secara aktif berpartisipasi di dalam proses belajar mengajar. Jika situasi belajar sudah menyenangkan bagi siswa, nantinya akan mudah bagi siswa untuk memahami materi yang akan dipelajari.

Mengajar bukan hanya menyampaikan apa yang ada dibuku paket kepada siswa tanpa memperhatikan tingkat pola pikir siswa. Mengajar adalah bagaimana guru bisa menanamkan sebuah konsep materi yang nantinya bisa dipahami oleh siswa. Jika siswa paham, sudah bisa dipastikan kalau siswa tidak akan lupa akan materi yang telah dipelajarinya. Sebaliknya, jika siswa hanya menghafal, maka keesokan harinya siswa akan mudah lupa dengan apa yang telah dipelajarinya.

Penanaman konsep materi harus ditanamkan sejelas mungkin kepada siswa, misalnya dengan dihadirkannya media maka siswa dapat mudah memahami materi. Menciptakan situasi belajar yang menyenangkan akan membuat siswa mudah dalam memahami materi yang diajarkan guru. Berdasarkan uraian di atas, maka dilakukan suatu penelitian yang memfokuskan pada pengaruh penerapan model pembelajaran kooperatif teknik berkirim salam dan soal terhadap kemampuan pemahaman matematis siswa di SMP Negeri 12 Kota Bima. 


\section{METODE PENELITIAN}

Metode yang dipakai dalam penelitian ini adalah metode eksperimen semu (quasi experimental). Penelitian ini menggunakan satu kelas eksperimen dan satu kelas kontrol. Pada kelas eksperimen diberi perlakuan pembelajaran dengan model pembelajaran kooperatif teknik berkirim salam dan soal. Sedangkan kelas kontrol diberi perlakuan pembelajaran dengan pembelajaran konvensional dengan metode diskusi, ceramah dan tanya jawab. Sebelum dimulai pembelajaran, kelas eksperimen dan kelas kontrol diberi tes awal atau pretest. Selanjutnya kelas eksperimen diberi perlakuan pembelajaran dengan model pembelajaran kooperatif teknik berkirim salam dan soal dan kelas kontrol diberi perlakuan pembelajaran dengan pembelajaran konvensional. Setelah selesai pembelajaran, kelas eksperimen dan kelas kontrol diberi tes akhir atau posttest. Desain penelitian yang digunakan dalam penelitian ini adalah control group pretest and posttest design.

Populasi dari penelitian adalah seluruh siswa kelas VIII yang terdiri dari tiga kelas yaitu kelas VIII A sampai dengan kelas VIII C yang berjumlah 75 siswa di SMP Negeri 12 Kota Bima. Pengambilan sampel dalam penelitian ini menggunakan metode cluster random sampling. Pengambilan sampel dikondisikan dengan pertimbangan bahwa siswa mendapatkan materi berdasarkan kurikulum yang sama, siswa yang menjadi objek penelitian duduk pada kelas yang sama dan kemampuan yang sama. Sampel yang digunakan dalam penelitian ini adalah siswa yang terdiri dari satu kelas yang ditentukan secara acak dari tiga kelas yang ada yaitu kelas VIII B sebagai kelas eksperimen yang dikenai perlakuan model pembelajarn kooperatif teknik berkirim salam dan soal, sedangkan kelas VIII A sebagai kelas kontrol yang diberi pembelajaran konvensional. Variabel dalam penelitian ini ada dua macam yaitu variabel bebas dan variabel terikat.Variabel bebas merupakan variabel yang variabelitasnya diukur, dimanipulasi atau dipilih untuk menentukan hubungannya dengan suatu gejala yang diobservasi. Adapun variabel bebasnya adalah model pembelajaran kooperatif teknik berkirim salam dan soal, variabel terikat adalah variabel yang variabelitasnya diamati dan diukur untuk menentukan pengaruh yang disebabkan oleh variabel bebas. Sementara itu, yang menjadi variabel terikat adalah kemampuan pemahaman matematis.

Teknik pengumpulan data adalah caracara yang digunakan untuk mengumpulkan data. Teknik yang digunakan dalampenelitian ini adalah tes. Menurut Arikunto (2009), tes adalah alat atau prosedur yang digunakan untuk mengukur sesuatu dengan cara dan aturanaturan yang telah ditentukan. Bentuk tes yang digunakan pada penelitian ini adalah tes tertulis. Tes yang akan digunakan dalam penelitian ini telah diteliti validitas, reliabilitas, daya pembeda, dan taraf kesukaran dari tiaptiap butir tes sebelum digunakan. Tes dilakukan untuk memperoleh data sebelum dan setelah eksperimen diadakan. Tes ini digunakan sebagai cara memperoleh data kuantitatif yang selanjutnya diolah untuk menguji hipotesis.

Dalam penelitian ini jenis soal yang menjadi instrumen tes merupakan soal yang digunakan untuk mengukur kemampuan pemahaman matematis siswa sehingga digunakan bentuk tes uraian. Tes yang dilakukan meliputi tes kemampuan awal dan tes kemampuan akhir pemahaman matematis. Tes kemampuan awal digunakan untuk mengetahui kemampuan pemahaman matematis yang dimiliki oleh siswa sebelum diberikan perlakuan yang berbeda untuk tiap kelas. Tes kemampuan akhir digunakan untuk mengetahui kemampuan pemahaman matematis siswa setelah melalui proses pembelajaran menggunakan model pembelajaran kooperatif teknik berkirim salam dan soal untuk kelas eksperimen dan akhir pembelajaran untuk kelas kontrol yang menggunakan pembelajaran konvensional. Sebelum soal tes digunakan, terlebih dahulu dilakukan uji instrumen soal yang mencari bagaimana validitas, reliabilitas, daya pembeda dan tingkat kesukaran dari soal itu sendiri. Jika dari hasil uji soal dinyatakan sudah memenuhi kriteria, maka selanjutnya dapat dijadikan sebagai instrumen penelitian. 
Analisis data menggunakan bantuan software SPSS versi 21 or windows dan Excel. Data tes diolah menggunakan analisis data pretes, data posttest, uji normalitas, homogenitas variansi, dan uji hipotesis menggunakan uji independent sample t-test.

\section{HASIL DAN PEMBAHASAN}

Penelitian ini dilaksanakan di SMP Negeri 12 Kota Bima. Penelitian ini menggunakan kelas VIII sebagai populasi. Dari populasi siswa yang terbagi atas tiga kelas, diambil dua kelas sebagai sampel. Sampel dalam penelitian ini ditentukan secara acak dari tiga kelas dengan teknik cluster random sampling. Pada tahap awal sebelum diberikan perlakuan, terlebih dahulu dipilih dengan cara mengambil satu kelas sebagai kelas eksperimen yaitu kelas VIII B, satu kelas lagi sebagai kelas kontrol yaitu kelas VIII A dan satu kelas sebagai kelas uji coba yaitu kelas VIII C. Setelah didapat tiga kelas yang masing-masing sebagai kelas eksperimen, kelas kontrol, kelas uji coba tes terkait kemampuan pemahaman matematis.

Proses penelitian dilanjutkan dengan merancang perangkat pembelajaran yang digunakan dalam penelitian. Perangkat pembelajaran yang dibuat berupa: (1) Silabus, (2) RPP, (3) LKS, (4) tes kemampuan pemahaman matematis. Setelah itu perangkat pembelajaran diuji cobakan kepada siswa. Perangkat pembelajaran yang diuji cobakan adalah tes kemampuan pemahaman matematis. Uji coba dilakukan untuk mendapatkan perangkat pembelajaran yang lebih baik. Hasil uji coba dianalisis dengan uji validitas, uji reliabilitas, daya pembeda, dan tingkat kesukaran soal.

Proses pembelajaran dilaksanakan tanggal 23 juli 2018 sampai dengan 10 agustus 2018. Pelaksanaan pembelajaran pada siswa kelas eksperimen dan kontrol masing-masing dilaksanakan enam kali pertemuan dengan rincian satu kali pertemuan pretest terkait kemampuan pemahaman matematis, empat kali pertemuan pembelajaran menggunakan model, dan satu kali pertemuan posttest terkait kemampuan pemahaman matematis.
Pada pertemuan pertama, baik kelas eksperimen maupun kelas kontrol, 20 menit pertama digunakan sebagai perkenalan dan penjelasan secara singkat tentang penilaian. Sedangkan 70 menit selanjutnya digunakan untuk pretest terkait kemampuan pemahaman matematis. Pertemuan selanjutnya, pembelajaran menggunakan model pembelajaran kooperatif teknik berkirim salam dan soal mulai diterapkan pada kelas eksperimen selama empat kali pertemuan, di mana setiap pertemuan terdiri dari $2 \times 45$ menit. Begitu juga pada kelas kontrol, mulai diterapkan pembelajaran konvensional selama empat kali pertemuan, di mana setiap pertemuan terdiri dari $2 \times 45$ menit.

Pertemuan selanjutnya, dilakukan post test kemampuan pemahaman matematis. Tes kemampuan pemahaman matematis digunakan untuk mengukur kemampuan pemahaman matematis siswa setelah model pembelajaran kooperatif teknik berkirim salam dan soal. Penelitian dilajutkan dengan menganalisis atau mengolah data yang telah dikumpulkan dengan metode-metode yang telah ditentukan. Hasil analisis digunakan untuk menjawab hipotesishipotesis dalam penelitian dan menarik simpulan.

\section{UJI COBA}

Setelah melaksanakan uji coba instrumen, hasilnya dianalisis untuk mengetahui validitas, reliabilitas, daya pembeda , dan tingkat kesukaran soal. Soal-soal yang memenuhi kriteria akan digunakan untuk penelitian kemampuan pemahaman matematis dan yang belum memenuhi kriteria akan diperbaiki atau dibuang. Dari proses perhitungan analisis validitas, reliabilitas, daya pembeda, dan tingkat kesukaran soal, maka butir soal uji coba tes kemampuan pemahaman matematis yang digunakan untuk mengambil data kemampuan pemahaman matematis siswa pada penelitian ini sebanyak 5 butir soal dari 10 soal yang diberikan, yaitu butir nomor: $2,4,6$, 7, dan 10.

\section{PRETEST}

Peneliti melaksanakan pretest untuk mengetahui gambaran awal sejauh mana 
kemampuan pemahaman matematis siswa. Uji normalitas pretest dilakukan terhadap data kemampuan pemahaman matematis siswa pada kelas ekperimen dan kelas kontrol. Hasil analisis tentang uji normalitas adalah sebagai berikut:

\begin{tabular}{|c|c|c|c|c|}
\hline \multirow{2}{*}{$I$} & \multicolumn{2}{|c|}{ Vilai Sigififkan } & \multirow{2}{*}{ a } & Kesimpulan \\
\cline { 2 - 3 } & Eksperimen & Kontrol & & \\
\hline 25 & 0,307 & 0,614 & 0,05 & Nomal \\
\hline
\end{tabular}

Perhitungan pada data pretest kemampuan matematis kelas eksperimen diperoleh nilai signifikansi sebesar 0,307, sedangkan nilai signifikansi kemampuan matematis kelas kontrol sebesar 0,614. Karena nilai signifikansi kemampuan matematis kelas eksperimen dan kelas kontrol lebih besar 0,05, maka dapat disimpulkan bahwa data pretest kemampuan matematis pada kelas eksperimen dan kelas kontrol berasal dari populasi berdistribusi normal.

Melihat data normal kemudian dilakukan uji $\mathrm{F}$ homogenitas diperoleh nilai sign yaitu 0,826 . Nilai sign ini lebih besar dari pada taraf signifikansi $\alpha=0,05$. Sehingga menurut kriteria pengambilan keputusan menyatakan bahwa $\mathrm{H}_{0}$ di tolak, atau dengan kata lain kedua varians homogen (sama) dan hasilnya dapat diterima.

\section{POSTTEST}

Setelah materi selesai diberikan, pemberian soal posttest kembali diberikan kepada siswa untuk mengetahui sejauh mana hasil treatmen yang dilaksanakan oleh peneliti. Uji normalitas posttest dilakukan terhadap data kemampuan pemahaman matematis siswa pada kelas ekperimen dan kelas kontrol. Hasil analisis tentang uji normalitas adalah sebagai berikut:

\begin{tabular}{|c|c|c|c|c|}
\hline \multirow{2}{*}{$\mathbf{N}$} & \multicolumn{2}{|c|}{ Nilai Signifikan } & \multirow{2}{*}{$\alpha$} & Kesimpulan \\
\cline { 2 - 3 } & Eksperimen & Kontrol & & \\
\hline 25 & 0,318 & 0,537 & 0,05 & Normal \\
\hline \multicolumn{5}{|c|}{ Perhitungan pada data posttest } \\
\hline
\end{tabular}

kemampuan matematis kelas eksperimen diperoleh nilai signifikansi sebesar 0,318, sedangkan nilai signifikansi kemampuan matematis kelas kontrol sebesar 0,537. Karena nilai signifikansi kemampuan matematis kelas eksperimen dan kelas kontrol lebih besar 0,05, maka dapat disimpulkan bahwa data posttest kemampuan matematis pada kelas eksperimen dan kelas kontrol berasal dari populasi berdistribusi normal.

Melihat data normal kemudian dilakukan uji $\mathrm{F}$ homogenitas diperoleh nilai sign yaitu 0,719 . Nilai sign ini lebih besar dari pada taraf signifikansi $\alpha=0,05$. Sehingga menurut kriteria pengambilan keputusan menyatakan bahwa kedua varians homogen.

Setelah dilakukan uji normalitas dan uji homogenitas yaitu diperoleh datanya berdistribusi normal baik pada kelompok kontrol maupun kelompok eksperimen, kemudian homogenitasnya juga terpenuhi karena kedua sampel tersebut berdasarkan perhitungan ternyata termasuk pada kriteria sampel homogen. Dengan demikian maka pengujian hipotesis dengan menggunakan rumus yang ditetapkan yaitu uji independent sample t-test dapat dilanjutkan.

\begin{tabular}{|c|c|c|c|c|}
\hline \multirow[t]{2}{*}{ Keterangan } & \multicolumn{2}{|c|}{ Pretest } & \multicolumn{2}{|c|}{ Posttest } \\
\hline & Eksperimen & Kontrol & Eksperimen & Kontrol \\
\hline Nilai Signifikan & \multicolumn{2}{|c|}{0,785} & \multicolumn{2}{|c|}{0,000} \\
\hline$\alpha$ & \multicolumn{2}{|c|}{0,05} & \multicolumn{2}{|c|}{0,05} \\
\hline Kesimpulan & \multicolumn{2}{|c|}{ Tidak Berbeda } & \multicolumn{2}{|c|}{ Berbeda } \\
\hline
\end{tabular}

Jika nilai signifikan atau nilai sig.(2tailed) $>0,05$, maka data tidak berbeda signifikan. Hasil perhitungan diperoleh nilai signifikansi pada hasil pretest sebesar 0,785. Sesuai dasar pengambilan keputusan dalam uji independent sample t-test adalah terima $\mathrm{Ha}$ karena nilai signifikansi adalah 0,785 ( $\alpha=$ $0,05)$, maka dapat dikatakan data tidak berbeda signifikan. Ini artinya bahwa tidak terdapat perbedaan antara rata-rata pretest kelas eksperimen dengan kelas kontrol.

Jika nilai signifikan atau nilai sig.(2tailed) < 0,05, maka data berbeda signifikan. Hasil perhitungan diperoleh nilai signifikansi pada hasil posttest sebesar 0,000. Keputusan yang diperoleh adalah terima $\mathrm{HO}$ karena nilai signifikansi adalah 0,000 $(\alpha=0,05)$, maka dapat dikatakan data berbeda signifikan. Ini artinya bahwa terdapat perbedaan antara ratarata posttest kelas eksperimen dengan kelas kontrol.

\section{KESIMPULAN}


Berdasarkan hasil penelitian maka kesimpulan yang dapat diambil dari penelitian ini adalah penerapan model pembelajaran kooperatif teknik berkirim salam dan soal memberikan pengaruh yang positif terhadap kemampuan pemahaman matematis siswa. Penerapan model pembelajaran kooperatif teknik berkirim salam dan soal memberikan kontribusi terhadap pencapaian kemampuan pemahaman matematis siswa yaitu pada kelas eksperimen diperoleh rata-rata skor sebesar 27,9, sedangkan rata-rata skor kemampuan pemahaman matematis siswa yang menggunakan pembelajaran konvensional sebesar 8,15.

\section{RUJUKAN}

Anwar, K. \& Harmi, H. (2011). Perencanaan Sistem Pembelajaran Kurikulum Tingkat Satuan Pendidikan (KTSP). Bandung: Alfabeta.

Arikunto, S. (2009). Dasar-Dasar Evaluasi Pendidikan : Edisi Revisi. Jakarta: Bumi Aksara.

Cahyaningtyas, M. (2013). Penerapan Model Pembelajaran Kooperatif Teknik Berkirim Salam dan Soal Untuk meningkatkan Minat dan Hasil Belajar Sosiologi Siswa Kelas X-1 SMA Negeri 5 Surakarta Tahun Pelajaran 2012/2013. Sosialitas jurnal ilmiah pend. Sosant vol 3, no 1.

Djamarah, S.B.(2002). Psikologi Belajar. Jakarta: Rineka Cipta.

Djamarah dan Zain. (2010). Startegi Belajar Mengajar. Jakarta: Rineka Cipta.

Lie, A. (2003). Cooperative Learning. Jakarta: Rineka Cipta. (2010). Cooperative Learning. Jakarta: Gramedia.

Pribadi, B. A. (2011). Model Assure untuk Mendesain Pembelajaran Sukses. Jakarta: PT Dian Rakyat.

Rusman. (2012). Model-model Pembelajaran Mengembangkan profesionalisme Guru. Bandung: Rajagrafindo Persada.

Slameto. (2003). Belajar dan Fakto-Faktor Yang Mempengaruhinya. Jakarta: Rineka Cipta. Sudijono, A. (2011). Pengantar Statistik Pendidikan. Jakarta: Raja Grafindo Persada.
Suprijono, A. (2009). Cooperative Learning Teori dan Aplikasi Paikem. Yogyakarta: Pustaka Pelajar. (2011). Cooperative Learning.

Yogyakarta: Pustaka Belajar.

Suyono dan Hariyanto. (2012). Belajar dan Pembelajaran. Bandung: PT Remaja Rosdakarya.

Tianto. (2007). Model-model Pembelajaran Inovatif Berorientasi Konstruktivistik. Jakarta: Prestasi Pustaka.

Wahyuni, D. (2004). Studi Tentang Pembelajaran Kooperatif Terhadap Hasil Belajar Matematika. Malang: Program Sarjana Universitas Negeri Malang.

Warsono dan Hariyanto. (2012). Pembelajaran Aktif

Teori dan Asesmen. Bandung: PT Remaja Rosdakarya.

Winataputra, U.S. (2008).Teori Belajar Dan Pembelajaran. Jakarta: Universitas Terbuka. 